\title{
Opções preferenciais: Solicitude e desprendimento como temas de teologia e diálogo na perspectiva de Puebla, fundamentos bíblicos e ênfases do Papa Francisco
}

\author{
Preferential Options: \\ Solicitude and detachment as theological and \\ dialogical themes in the perspective of Puebla, biblical \\ bases and emphases of Pope Francis
}

Maria Teresa de Freitas Cardoso

\section{Resumo}

O artigo contempla o Documento de Puebla, que foi preparado na perspectiva da evangelização, particularmente destacando a opção pelos pobres e o espírito das bem-aventuranças. Considera diversos textos bíblicos do Antigo e do Novo Testamento relacionados com a predileção do evangelho, especialmente o ideal régio compartilhado nas culturas do Oriente Médio e o anúncio evangélico do Reino de Deus, espírito das bem-aventuranças. Apresenta algumas ênfases feitas pelo Papa Francisco para o Dia Mundial do Pobre, onde o papa afirma que o protagonismo é de Deus, e algumas de suas palavras sobre as bem-aventuranças a propósito da santidade hoje. Valoriza o aspecto dialogal da temática.

Palavras-chave: Evangelho. Práxis cristã. Documento de Puebla. Papa Francisco. Diálogo. 


\begin{abstract}
The article looks at the Puebla document written in the perspective of evangelization and option for the poor, together with the spirit of the Beatitudes. It considers different biblical texts of the Old and New Testaments related to the preferential option of the Gospel, especially the royal ideal shared in the cultures of the Middle East and the evangelical announcement of the Kingdom of God, and also the spirit of the Beatitudes. It identifies the emphases made by Pope Francis for the World Day of the Poor, where the Pope affirms that primacy belongs to God, and presents some of his words about the Beatitudes referring to holiness today. It highlights the dialogical aspect of the themes.
\end{abstract}

Keywords: Gospel. Christian praxis. Puebla Document. Pope Francis. Dialogue.

\title{
Introdução
}

Na Conferência de Puebla, examina-se o contexto da América Latina com os critérios da fé e da práxis cristã e repropõem-se diretrizes pastorais em função do tema basilar da evangelização. Está subjacente à proposta de Puebla a chamada predileção evangélica, pela qual se orientam as suas opções preferenciais, em continuidade com Medellín. Puebla tem como inspiração geral a proposta de promover uma evangelização libertadora e de viver o espírito das bem-aventuranças. Propõe também uma opção preferencial pela juventude.

A proposta de Puebla faz parte da reflexão teológica latino-americana, que encontrou apoio no episcopado, no clero e, largamente, em contextos dos leigos, das comunidades de base e outras comunidades. Está presente na vida do povo de Deus e atravessa as conferências episcopais seguintes, reavivandose de modo novo em Aparecida. A contribuição amadurecida e renovada de Aparecida, que sinaliza uma mudança de época, vem lançar-se para a pastoral da Igreja toda. Hoje, as opções fundamentais do Evangelho, junto com a busca de amplos diálogos e convocando a uma atenção para com os pobres, os que sofrem, e a fragilidade do planeta, são acentuadas pelo Papa Francisco.

Este artigo recolhe um pouco desses elementos. Em primeiro lugar, discorre sobre a proposta de Puebla no seu ideal de evangelização, a inspirar o modo de ser e de agir da Igreja, não somente em vista daquele momento, mas já 
em perspectiva de futuro. Identifica-se que esse ideal constitui o próprio eixo da reflexão de Puebla. Em segundo lugar, desenvolve-se um estudo bíblico. Após breve terminologia do Antigo e do Novo Testamento, consideram-se vários textos sobre o agir salvífico de Deus nos quais ressoa o ideal régio desejado no Oriente Médio e abraçado na Bíblia, em diálogo com expressões religiosas e culturais circunvizinhas, o qual está na base do Evangelho proclamado por Jesus Cristo. O estudo se completa com observações sobre o espírito das bemaventuranças. Em um terceiro momento, pela comemoração dos 40 anos de Puebla, logo após a comemoração dos 50 de Medellín, tomam-se observações recentes da teologia e destacam-se observações feitas pelo Papa Francisco sobre o núcleo da fé, da práxis do evangelho e sobre o clamor dos pobres que deve ser escutado, bem como a importância de se buscar diálogos e estender as mãos em vista de uma colaboração. A conclusão entrelaça esses aspectos para valorizar uma teologia em diálogo.

\section{No horizonte de Puebla: evangelização e opção preferencial pelos pobres}

$\mathrm{Na}$ ótica do documento conclusivo da III Conferência Geral do Episcopado Latino Americano, de 1979, de Puebla, e como seu eixo temático, estão as opções e predileções do Evangelho. O título assumido pelo CELAM a conferência foi: "A evangelização no presente e no futuro da América Latina". Isso faz incidir na reflexão pastoral uma referência da fé cristã: o Evangelho. Para a igreja latino-americana, assim como deve ser para toda a Igreja, colocase o chamado à evangelização, que tem apoio em fundamentos teológicos e leva a compromissos com uma práxis concreta.

No discurso inaugural da conferência, pronunciado pelo Papa João Paulo II, em 28 de janeiro de 1979, indicavam-se pistas para o trabalho, e se orientava para: aprofundar a verdade sobre Jesus Cristo, a missão da Igreja, o homem; para indicar o serviço pastoral dos bispos como sinais e construtores da unidade; para promover a defesa e a promoção da dignidade humana e aqui se recordava que a Igreja, na expressão de Paulo VI, é "perita em humanidade" porque defensora dos direitos humanos; e isso, explicitava João Paulo II, dado que "um autêntico compromisso evangélico, como sucedeu com Cristo, é, sobretudo, compromisso com os mais necessitados". ${ }^{1}$ Dessa

${ }^{1}$ JOÃO PAULO II, PP., Discurso inaugural, p.29. 
temática e desse compromisso vital desdobra-se todo o Documento de Puebla, e nele sobressairão "algumas tarefas prioritárias". ${ }^{2}$

1.1. O tema da evangelização nas duas primeiras partes do Documento de Puebla

A Apresentação do Documento de Puebla rememora o processo de preparação da Conferência pela participação das igrejas da América Latina, tendo feito um instrumento de trabalho que serviu de orientação. Observa-se que o propósito não era formar um tratado de teologia dogmática ou pastoral, mas "considerar aspectos de maior incidência na evangelização", para a Igreja lançar-se "com renovado vigor no serviço dos nossos povos", no espírito de "comunhão e participação", e "mediante a evangelização plena" atuar para o homem "viver a filiação em fraternidade", de modo que seja imagem viva de Deus dentro da Igreja e do mundo" e nessa qualidade "sujeito ativo da história". ${ }^{3}$

A Mensagem aos Povos da América Latina tinha em vista a participação de todos os homens de boa vontade (todos os homens e todas as mulheres) em direção, de novo na linguagem de Paulo VI, a uma "civilização do amor", dado que "o amor gera a felicidade da comunhão e inspira os critérios da participação". E também "a justiça", que "é um direito sagrado de todos os homens, conferido pelo próprio Deus", ela "está enxertada na própria essência da mensagem evangélica". Acentua-se que "a verdade, esclarecida pela fé, é fonte perene de discernimento para nosso comportamento ético". Acrescenta-se "a liberdade" como "dom precioso de Deus" e condição e fator para o progresso. Essa civilização do amor "repudia a violência, o egoísmo, o esbanjamento, a exploração e os desatinos morais", e, ao contrário, toma como necessário "colocar muita renúncia e solidariedade para o correto equilíbrio das relações humanas". ${ }^{4}$

No Documento de Puebla, a parte I descreve uma visão pastoral sobre a realidade latino-americana. Essa primeira parte inicia com uma visão histórica. Refere-se à atuação da Igreja e sua missão "em busca do Reino definitivo". Menciona a confluência de diversas raças e culturas. Observa que houve "lutadores em prol da justiça e evangelizadores de paz". Especialmente

${ }^{2}$ JOÃO PAULO II, PP., Discurso inaugural, p.33.

${ }^{3}$ BAGGIO, S.; LORSCHEIDER, A.; CORRIPIO AHUMADA, E., Apresentação, p. 49-50.

${ }^{4}$ DP 8 . 
"a partir de Medellín, tem conseguido a Igreja uma nítida consciência de sua missão", ao passo em que "tem-se aberto com lealdade ao diálogo" em vista de "uma sociedade nova, mais justa e mais fraterna". ${ }^{5}$

O capítulo II concentra-se na visão sociocultural. Tem em conta que peregrinamos, mas deve ser "partindo do Evangelho que nos apresenta Jesus Cristo como o que passou fazendo o bem e amando a todos sem distinção" (o texto reporta-se a At 10,38). Por isso, é preciso "discernir as interpelações de Deus nos sinais dos tempos, a dar testemunho, a anunciar e a promover os valores evangélicos". ${ }^{6}$ Constatam-se no contexto sociocultural dos povos latino-americanos esses diversos valores evangélicos. A conferência de Puebla faz-se solidária de todos os membros do povo, "qualquer que seja a sua condição social", e comprova como "devastador e humilhante flagelo a situação de pobreza" e todas as outras "angústias que brotam da falta de respeito à sua dignidade de ser humano". ${ }^{7}$

Já no capítulo III a visão volta-se para aspectos da realidade eclesial. Levanta indagações sobre o modo de a Igreja olhar e interpretar a realidade daquele contexto, e sobre se estava realizando os planos de Deus, a missão salvadora, de evangelizar. Depois considera o clamor do "povo que sofre e reclama justiça, liberdade e respeito" e tem em mente que esses "são desafios lançados à evangelização". ${ }^{8}$ Constata passos dados de comunhão eclesial e explicita entre os avanços a "atividade ecumênica, expressa no diálogo e nos esforços conjuntos em favor da promoção humana", que "inscreve-se no caminho que leva à unidade desejada" e revaloriza a religiosidade popular. ${ }^{9}$

O capítulo IV traça várias tendências de então e vislumbra a evangelização no futuro, que "dará prioridade à proclamação da Boa-Nova" e tomará vários compromissos catequéticos, litúrgicos, pastorais, de formação e engajamento em especial dos leigos, esforços de comunicação e de serviços.

A segunda parte discorre sobre o desígnio de Deus para a realidade da América Latina. Pergunta por esse desígnio e pelo empenho em caminhos de libertação. O primeiro capítulo trata do conteúdo da evangelização com verdades centrais sobre Cristo, sobre a Igreja e sobre o Homem. Na sua referência a Cristo, destacam-se seus ditos e feitos - o que foi a vida de

\footnotetext{
${ }^{5}$ DP 3-13.

${ }^{6} \mathrm{DP} 15$.

${ }^{7}$ DP $27-44$.

${ }^{8}$ DP $87-90$.

${ }^{9}$ DP 108-109.
} 
Jesus. Nesse ponto, lembra que "o povo [...] esperava a libertação [...] No meio dele Jesus anuncia: 'Completou-se o tempo; chegou o Reino de Deus. Convertei-vos e crede no Evangelho’ (Mc 1,15). Ungido pelo Espírito Santo para anunciar o Evangelho aos povos, para proclamar a liberdade dos cativos..."; e em seguida a reflexão rememora as Bem-aventuranças e o Sermão da Montanha como "grande proclamação da Nova Lei do Reino de Deus. São indicadas outras referências bíblicas, além de Mc 1,15; também Lc 4,18-19; Mt 5,1-12. Observa-se que "às palavras Jesus juntou os fatos", pelo que realizou concretamente, como sinal. Houve, de outras partes, incredulidade e incompreensões, mas Jesus "empreende seu caminho de doação", com uma "doação desinteressada e sacrificada do amor. Amor que abraça a todos. Amor que privilegia os pequenos, os fracos, os pobres. Amor que congrega e integra a todos em uma fraternidade". Jesus atravessa o mistério pascal e permanece identificado "com os mais fracos e os mais pobres" (recorda-se Mt 25,40). Acrescenta-se que a proclamação da Boa Nova chama ao batismo e à vida segundo o Evangelho, o que se torna motivo de esperança.

Em seguida, o Documento discorre sobre o Espírito e sobre a Igreja. O Espírito comunicado é Espírito de filiação, verdade e vida, amor e liberdade, unidade e diversidade. A Igreja deve peregrinar na humildade, reconhecendo erros e pecados, decidida à evangelização, para promover comunhão e a libertação da criação inteira. ${ }^{10}$ Desse modo, prossegue lembrando que a verdade da Igreja é ser sinal e serviço de comunhão, fiel ao Evangelho e ao Reino. Lembra ainda, entre outras considerações, que o povo de Deus é povo servidor. Ao discorrer sobre a verdade do ser humano, tem em conta que ela se coloca na "dignidade que é própria de todos", de "todo homem e toda mulher". Deste modo, seu serviço de todos, a Igreja deve fazer revisão da própria vida, anunciar o Evangelho e fazer a denúncia profética quando necessário, e procurar viver "no espírito das bem-aventuranças". ${ }^{11}$

O capítulo II dessa parte desdobra o que seja e como fazer a evangelização, bem como identifica vários desafios encontrados. O texto reporta-se à exortação apostólica Evangelii Nuntiandi, para acentuar "a interpelação recíproca que ao longo dos tempos se estabelece entre o Evangelho e a vida concreta, pessoal e social do homem (EN 29)" 12 e

\footnotetext{
${ }^{10}$ DP $188-220$.

${ }^{11}$ DP 314-339.

${ }^{12}$ DP 476.
} 
para procurar por uma "evangelização libertadora para uma convivência humana digna dos filhos de Deus". ${ }^{13}$

\subsection{O aspecto dialogal e uma opção preferencial}

Já a parte III do Documento de Puebla, no contexto da evangelização pela comunhão e participação, evidenciam-se, no capítulo I, centros e linhas de ação, e no capítulo II diretamente os agentes, a situação, os critérios e as ações a empreender. O capítulo III busca os meios de agir. Todas essas considerações são importantes e caberia em nosso tempo rever os mesmos tópicos para os contextos mais atuais. Já o capítulo IV atravessa um tema capital proposto neste artigo e, por isso, será desdobrado a seguir.

O capítulo IV trata do necessário diálogo para a evangelização em seus anúncios e práxis. O diálogo recebe uma seção específica e ele é contemplado em vários círculos de abrangência, de modo semelhante ao que se vislumbrava na encíclica Ecclesiam Suam, de Paulo VI: diálogo entre cristãos, com os judeus, com todas as pessoas, crentes e não crentes, tendo-se em conta a vontade salvífica universal, que não exclui ninguém. Nesse contexto dialogal, retoma-se a observação da Gaudium et Spes n. 19, para lembrar que a "nãocrença constitui uma interpelação e um desafio à fidelidade e autenticidade dos crentes e da Igreja". ${ }^{14}$ Aplica-se certamente de modo especial ao empenho para realização das opções do Evangelho.

Quanto às duas últimas partes do Documento de Puebla, encontramos dados conclusivos: a parte IV, sobre a ação missionária a serviço, orienta para algumas opções preferenciais, sendo que a primeira descreve-se como opção preferencial pelos pobres e a segunda, opção pelos jovens. Já a parte V do Documento de Puebla é muito breve, mas não menos importante, sobre a vida no dinamismo do Espírito, e logo se resume a direção das opções pastorais em relação com uma expectativa de alegria e de esperança.

Destaca-se no capítulo I da quarta parte a "opção preferencial pelos pobres". Recordam-se traços do itinerário de Medellín a Puebla, marcado por essa "opção preferencial e solidária pelos pobres". Alude-se a interpretações errôneas, pois também as houve, mas se sublinha ainda "a necessidade de conversão de toda a Igreja para uma opção preferencial pelos pobres, no

\footnotetext{
${ }^{13}$ DP 491-506.

${ }^{14}$ DP 1117.
} 
intuito de sua integral libertação". ${ }^{15}$ Considera-se como a maioria dos irmãos está em situação de pobreza ou miséria, e faz-se um exame, em busca de pistas eficazes de ação evangelizadora, denúncias proféticas das injustiças, concluindo-se com uma reflexão doutrinal e várias linhas pastorais.

Na reflexão doutrinal, reporta-se ao dado bíblico de Jesus ter evangelizado os pobres. Daí o compromisso evangélico da Igreja, de ser como Cristo, no compromisso com os mais necessitados, visto que Jesus se solidarizou com os pobres e que todas as pessoas são criadas imagem e semelhança de Deus, que a todos ama e Deus toma os pobres em defesa. Eles são os primeiros destinatários da evangelização, como sinal da missão de Jesus. O texto referese a João Paulo II, que por sua vez assumia a solidariedade de Cristo com os pobres, e alude ao canto do Magnificat, pelo seu significado de compromisso com os pobres e de transformação da sociedade.

Prosseguindo a reflexão doutrinal, Puebla vê o serviço ao irmão pobre como fazer o que Cristo ensinou. Salienta que o serviço dos pobres deve ser privilegiado sem exclusivismo, ao passo que importa a sua evangelização e o cumprimento das exigências da justiça, suprimindo-se as causas de pobreza e organizando-se auxílios. Lembra o compromisso das Comunidades de base e o potencial evangelizador dos pobres, chamando à conversão. Constata que muitos deles são autênticos na solidariedade e no serviço e no acolhimento dos dons de Deus.

Daí se passa ao ideal de pobreza cristã. Esta não teria o significado primário de privação e marginalização, mas designaria um modelo de vida. Tal modelo teria aparecido no Antigo Testamento e vinha proposto nas bemaventuranças. Trata-se, na linguagem de Paulo, de usar os bens do mundo como se não se os utilizasse. De uma "abertura confiante em Deus com uma vida simples, sóbria e austera". ${ }^{16}$ De uma comunicação de bens materiais e espirituais, para que não haja mais necessitados.

\section{Nas opções preferenciais do Evangelho}

Ao rememorar a Conferência de Puebla, o leitor pode ir ao coração do Evangelho, às opções fundamentais do Evangelho. Embora o Documento não tenha pretendido ser um trabalho sistemático de teologia dogmática e pastoral,

\footnotetext{
${ }^{15}$ DP 1134.

${ }^{16}$ DP 1149.
} 
nem de pesquisa de exegese bíblica, situa-se no centro do necessário diálogo da teologia sistemático-pastoral com a perspectiva bíblica. É o que este artigo vem destacar.

Serve de referência, para melhor matizar as implicações da mensagem evangélica, a obra Les Béatitudes do clássico exegeta Jacques Dupont. ${ }^{17}$ Ele evidenciou de modo feliz o significado das predileções evangélicas e mostrou o seu fundamento teológico. Indicou as atitudes de humildade e despojamento que o seguimento do Evangelho também requer. $\mathrm{O}(\mathrm{a})$ leitor(a) é incentivado(a) a aprofundar-se na obra referida, ou mais simplesmente fazer uma leitura de um estudo sobre o assunto feito por esta autora anteriormente,,$^{18}$ que é bem mais longo do que esta seção do artigo, sendo, porém, aqui retomado, corrigido, adaptado ao propósito do novo estudo e assim levado a uma nova perspectiva, podendo-se perceber uma evolução do pensamento.

\subsection{A terminologia bíblica do pobre tem matizes diversos}

O termo "pobre", no idioma português, designa o que possui pouco, ou muito pouco, ${ }^{19}$ deriva do latim pauper, da raiz pau- (paucus), "pouco", diferindo dos egentes, que não possuem o necessário e dependem de auxílio. A terminologia bíblica abaixo retoma o estudo anterior indicado.

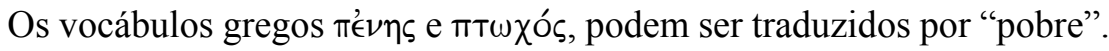
O primeiro seria o homem de poucos recursos, e o segundo, como egens, seria aquele a quem faltam meios de subsistência e depende de socorro, e

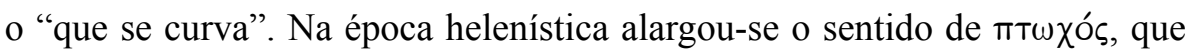
também se tornou mais frequente. Na LXX os termos foram tomados às vezes indistintamente, mas o grego bíblico deve ser interpretado considerando-se o seu substrato semita. No hebraico temos os vocábulos principais: 'ânî e 'ânâw, dal, 'èbyôn, râsh e miskén, ${ }^{20}$ e shâphâl.

\footnotetext{
${ }^{17}$ DUPONT, J., Les Béatitudes, t.2; DUPONT, J., Les Béatitudes, t.3.

${ }^{18}$ FREITAS CARDOSO, M. T. de, A predileção evangélica do pobre, p. 131-174.

${ }^{19}$ Segundo o dicionário de CALDAS AULETE o "pobre" é o "falto ou privado do necessário; que vive com poucas posses [...]. Que não tem recursos próprios [...]. Mal dotado, pouco favorecido [...]. Infeliz, desprotegido: digno de lástima ou de compaixão [...]”. CALDAS AULETE, pobre, p. 2857.

${ }^{20}$ Esses termos aparecem 245 vezes no AT designando os "pobres" e são traduzidos pela LXX

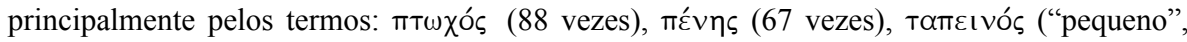
"humilde", 21 vezes) e mpaứ ("manso", "afável”, 12 vezes). GEORGES, A., A Pobreza segundo o Antigo Testamento, p. 12-13.
} 
'Anî e 'ânâw têm a mesma raiz 'ânâh, de etimologia discutida, mas em geral se admite o significado de "curvar-se", "estar curvado", evocando inferioridade, humilhação, submissão. ${ }^{21}$ "Anî é o "curvado", o "rebaixado"; aquele que, incapaz de resistir, submete-se. Pode designar o pobre, que se torna socialmente um fraco, indefeso, ${ }^{22}$ presa fácil para os poderosos, e muitas vezes um oprimido. ${ }^{23}$ Algumas vezes o 'ân $\hat{\imath}$ "humilde e submisso, que põe sua confiança em Deus e dele espera seu auxílio", ${ }^{24}$ passa a representar a atitude que se deve ter diante de Deus. ${ }^{25} \mathrm{O}$ sentido de 'ânâw (usado no plural, 'anâwîm, exceto em Nm 12,3) parece ter-lhe sido progressivamente preferido para a conotação moral e religiosa. Os 'anâwîm podem ser pobres, indefesos, oprimidos, infelizes; mas são sobretudo pessoas humildes, mansas, e confiantes em Deus, que as salvará. ${ }^{26} \mathrm{~A}$ "anâwâh — "humilde mansidão" é recomendada: "Procurai a Iahweh vós todos, os pobres ('anâwîm) da terra, que realizais a sua ordem. Procurai a justiça, procurai a pobreza ('anâwâh, humildade): talvez sejais protegidos no dia da ira de Iahweh" (Sf 2,3). ${ }^{27}$ Já o

${ }^{21}$ DUPONT, J., Les Béatitudes, t.2, p. 24-25. MARTIN-ACHARD, R., ' $n h$ II, col. 307. GEORGES, A., A Pobreza segundo o Antigo Testamento, p. 13-14. GÉLIN, A., Os Pobres que Deus ama, p. 20. LOSS, N. M., Il Tema della Povertà nei Libri Storici e Profetici dell'Antico Testamento, p. 55-56.

${ }^{22}$ S1 72,12: "Ele liberta o indigente ('èbyôn) que clama e o pobre ( 'ânî) que não tem protetor". GÉLIN, A., Pobres que Deus ama, p. 20. LOSS, N. M., Il Tema della Povertà nei Libri Storici e Profetici dell'Antico Testamento, p. 55-56.

${ }^{23}$ S1 74,21: "Não volte o oprimido (dak) coberto de confusão, que o pobre ( 'ânî) e o indigente ('èbyôn) louvem o teu nome"; 12,6; 14,6; Is 3,14s; 32,7; Ez 18,12; Am 8,4. GÉLIN, A., Pobres que Deus ama, p. 20. LOSS, N. M., Il Tema della Povertà nei Libri Storici e Profetici dell'Antico Testamento, p. 55-56.

${ }^{24}$ DUPONT, J., Les Béatitudes, t. 2, p. 26. O clamor do pobre a Deus é referido, por exemplo, no S1 34,7: "este pobre ( 'ânî) gritou e Iahweh ouviu, salvando-o de suas angústias todas".

${ }^{25}$ Trata-se do temor e da humildade diante de Deus, e da confiança em Sua salvação. Is 66,2b: "Eis para que estão voltados os meus olhos, para o pobre ( $\hat{a} n \hat{\imath})$ e para o abatido, para aquele que treme diante da minha palavra"; Sf 3,12: "Deixarei em teu seio um povo pobre ( 'ânî) e humilde, e procurará refúgio no nome de Iahweh".

${ }^{26}$ Os 'anâwîm são nomeados ao lado dos fracos (dallîm): Is 11,4; e ao lado dos justos, em contraposição aos ímpios, que os perseguem (aos justos, aos pobres, ao homem reto): S1 37,10ss.14. Também ocorrência em 25,$9 ; 34,3 ; 69,33 ; 147,6$. A escolha dos termos 'ânî e 'ânâw passa por hesitações; é o que vemos, por exemplo, em Pr 3,34; 14,21; 16,19; neste último caso, vemos K: 'aniyyîm, Q: 'anâwîm; a leitura confirma 'ânî em 14,21, mas em 3,34, prefere 'anâwîm. GÉLIN, A., Pobres que Deus ama, p. 20. LOSS, N. M., Il Tema della Povertà nei Libri Storici e Profetici dell'Antico Testamento, p. 55-56.

${ }^{27}$ Observa-se como a exortação é dirigida aos " "anâwîm da terra" e adverte para o cumprimento da ordem divina - "que realizais a sua ordem". Essa gente humilde, que pode passar despercebida (ou sem importância) aos olhos dos homens, ficará despercebida para a cólera de Iahweh. 
shâphâl é o que não se eleva, permanece junto ao solo (como o latino humilis): humilde, modesto, ${ }^{28}$ enquanto o 'ânâw se curva mansamente, o shâphâl permanece pequeno.

O termo dal significa "magro" (qualifica as sete vacas magras ou malalimentadas, dallôt, de Gn 41,19); opõe-se ao rico ('ashîr) (Êx 30,15; $\mathrm{Pr}$ $10,15)$; é o "fraco", também o pobre. ${ }^{29} \mathrm{O}$ 'èbyôn (da raiz 'âbâh, "querer", "desejar") é um pobre, pois faltam-lhe recursos, de modo que ele os deseja e pede: é um indigente ou pedinte. Socialmente fraco, quer auxílio e necessita que lhe façam justiça. ${ }^{30}$ Râsh é alguém desprovido. ${ }^{31}$ E miskén (raro na Bíblia) sugere dependência, precisando de algum auxílio. ${ }^{32}$

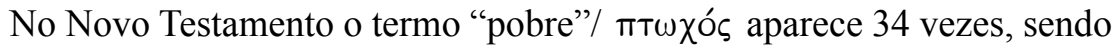

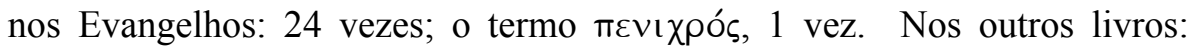

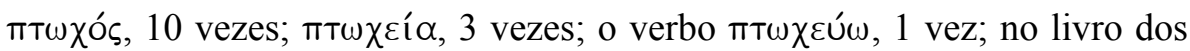

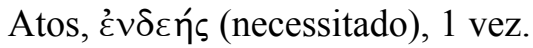

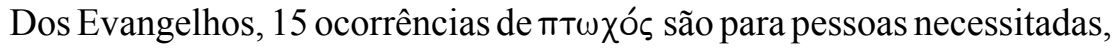
às quais se deve dar esmola: o jovem rico deve vender tudo e o dar "aos pobres" (Mt 19,21 // Mc 10,21 // Lc 18,22); na unção em Betânia, trata-se de dar "aos pobres", e Jesus diz: "sempre tereis os pobres" (Mt 26,9.11 // Mc 14,5.7 // Jo 12,5.6.8); Zaqueu decide dar metade de seus bens "aos pobres"

Acentua-se que o que Ele exige é o cumprimento de sua vontade, é procurar a Iahweh, procurar a justiça, procurar a 'anâwâh. Temos em Eclo 10,15 a oposição dos 'anâwîm aos orgulhosos,

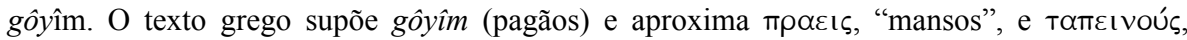
"pequenos" ou "humildes" - os dois aspectos do conceito moral-religioso de "anâwâh. Também 3,17 ("doçura"); 4,8 ("afabilidade"); 10,28 ("modéstia"), 13,20 ("humildade"), 45,4 ("doçura"); Pr 15,33 (“pobreza”). DUPONT, J., Les Béatitudes, t.2, p. 28.

${ }^{28} \mathrm{Em}$ sentido pejorativo, seria o que se rebaixa, 2Sm 6,22; Ml 2,9. Valorizado na expressão shephal-rûah, "humilde" de Pr 16,19; 29,23 ("pobre de espírito"); Is 57,15 ("humilhado"); e nas recomendações rabínicas: "seja muito, muito shephal-rûah". DUPONT, J., Les Béatitudes, t.2, p. 33; DUPONT, J., Les Béatitudes, t.3, p. 387-388.

${ }^{29}$ Is 10,2: "para desapossarem os fracos do seu direito e privar da sua justiça os pobres do meu povo, para despojar as viúvas e saquear os órfãos"; S1 82,3-4: "Protegei o fraco e o órfão, fazei justiça ao pobre e ao necessitado".

${ }^{30}$ Êx 23,6: "Não desviarás o direito do teu pobre em seu processo"; Am 5,12b: "Eles hostilizam o justo, aceitam suborno, e repelem os indigentes à porta"; Jr 5,28b: "não respeitam o direito, o direito dos órfãos e, todavia, têm êxito! E não fazem justiça aos indigentes". Também 22,16; S1 72,4; 140,13; Pr 31,9.

${ }^{31} \operatorname{Pr} 20,13$. O termo é típico da literatura sapiencial (exceção em $1 \mathrm{Sm} 18,23$ ), e bem frequente no livro dos Provérbios (14 vezes).

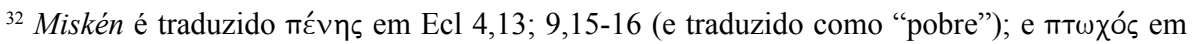
Eclo 4,3 (como "necessitado"). 
(Lc 19,8); Judas haveria de levar algo "para os pobres" (Jo 13,29); o "pobre" Lázaro da parábola era um miserável (Lc 16,20.22); o convite para uma festa é estendido aos "pobres" e demais desafortunados (Lc 14,13). O termo aparece para a "pobre" viúva (Mc 12,42.43 // Lc 21,3). Mantém-se a ideia de pessoas necessitadas ou de poucos recursos.

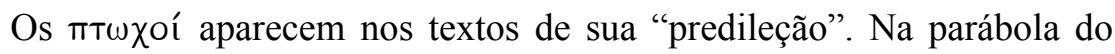
banquete são reunidos com outros desafortunados, e são beneficiários do Reino "os pobres, os enfermos, os cegos e os estropiados" (Lc 14,21). E nas cinco vezes restantes são destinatários da Boa Nova ou do Reino: Jesus lê o oráculo de Isaías proclamando "evangelizar os pobres" (Lc 4,18-19); na sua resposta aos discípulos de João Batista, relaciona entre os benefícios a evangelização dos "pobres" (Mt 11,4s // Lc 7,22); na primeira bem-aventurança, temos

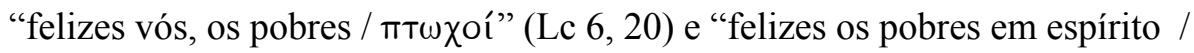

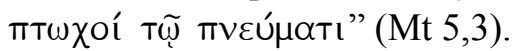

Em At 4,34, sobre a comunidade primitiva, "não havia entre eles

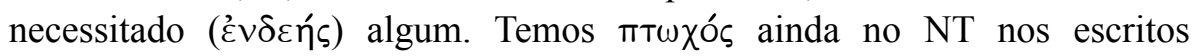
paulinos: "lembrar dos pobres" (G1 2,10); "uma coleta em prol dos santos de Jerusalém que estão na pobreza" (Rm 15,26); e: "somos tidos como tristes e, não obstante, sempre alegres; como indigentes e, não obstante, enriquecendo a muitos; como nada tendo, embora tudo possuamos!" (2Cor 6,10). Ou: "fracos e miseráveis elementos, aos quais vos quereis escravizar" (Gl 4,9). Temos a advertência de Tiago para não discriminar entre "duas pessoas, uma [...] ricamente vestida, e a outra pobre, [...] e derdes atenção ao que se traja ricamente [...] enquanto dizeis ao pobre: 'tu, fica em pé aí' [...]. Não escolheu Deus os pobres em bens deste mundo para serem ricos na fé e herdeiros do Reino que prometeu aos que o amam? E, no entanto, vós desprezais o pobre!" (Tg 2,2.3.5.6). No Apocalipse: "todos, pequenos e grandes, ricos e pobres, livres e escravos" (Ap 13,16); e no início do livro: “dizes: 'sou rico' [...]. Não sabes, porém, que és tu o infeliz: miserável, pobre, cego e nu!” (Ap 3,17).

Temos os termos $\pi T \omega \chi \varepsilon \varepsilon i ́ \alpha$ (pobreza) e $\pi T \omega \chi \varepsilon u ́ \omega$ (empobrecer): no elogio feito por Paulo: "em meio às múltiplas tribulações [...], a sua copiosa alegria e a sua pobreza extrema transbordaram em tesouros de liberalidade" (2Cor 8,2 ); na alusão ao exemplo de Cristo: "por causa de vós se fez pobre ( $\dot{\pi \top \omega ́ \chi \chi \varepsilon \cup \sigma \varepsilon v), ~ e m b o r a ~ f o s s e ~ r i c o, ~ p a r a ~ v o s ~ e n r i q u e c e r ~ c o m ~ a ~ s u a ~ p o b r e z a " ~}$ (v.9); e no Apocalipse: "Eu conheço tua tribulação, tua indigência; tu és rico, porém" (Ap 2,9). 
2.2. Entre as opções do evangelho: a solicitude libertadora e a humildade com desprendimento

Na predileção evangélica dos destinatários do Reino, temos proclamado que deles é o Reino dos "pobres" e "pobres em espírito"; e dos "pequenos".

No início do ministério de Jesus, ele faz a leitura do livro de Isaías (reconhece-se no fundo o oráculo de Is 61,1s). É o que vemos em Lc 4,18-19:

O Espírito do Senhor está sobre mim, porque ele me consagrou pela

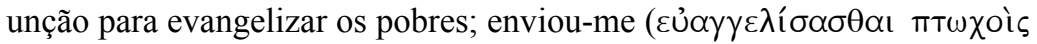

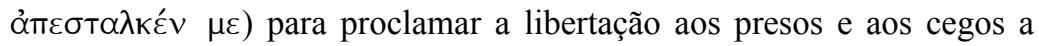
recuperação da vista, para restituir a liberdade aos oprimidos e para proclamar um ano de graça do Senhor.

Na resposta de Jesus (Lc 7,22) aos emissários de João, mostra-se o cumprimento das profecias:

Então lhes respondeu: "Ide contar a João o que vedes e ouvis: os cegos recuperam a vista, os coxos andam, os leprosos são purificados, os surdos ouvem, os mortos ressuscitam e aos pobres é anunciado o Evangelho" (

O oráculo de Isaías (Is 61,1-2) anunciava:

O Espírito do Senhor Iahweh está sobre mim, porque Iahweh me ungiu; enviou-me a anunciar a boa nova aos pobres ('anâwîm), a curar os quebrantados de coração e proclamar a liberdade aos cativos, a libertação aos que estão presos, a proclamar um ano aceitável a Iahweh e um dia de vingança do nosso Deus, a fim de consolar todos os enlutados.

Trata-se, portanto de uma boa nova, mensagem de consolação e libertação. Isso estará na tradução da LXX, como boa nova para os infelizes, e em um hino de Qumrân, sobre o mensageiro que anunciará a boa nova aos 'anâwîm e consolará os aflitos. O tema da consolação em Isaías prevê a intervenção divina para atender e consolar, socorrer e abençoar. Aparece o tema em Is 41,17; 49,7-10.13. Nessa linha reaparece em Is 61,1-2, que menciona os "pobres"

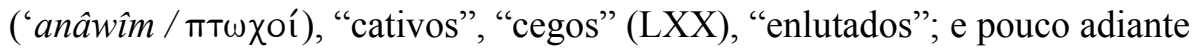
faz (vv.6-7) promessas de "alimentar" e proporcionar uma "alegria eterna". 
Os destinatários da boa nova são em especial pessoas que sofrem, às quais se anuncia libertação do sofrimento e, portanto, a alegria. Isso faz parte do tema da consolação.

A ideia de anúncio da Boa-nova vai relacionar-se diretamente com o Reino de Deus. Temos em Is 52,7 o mensageiro da Boa-nova: "Como são belos, sobre os montes, os pés do mensageiro que anuncia a paz, do que proclama boas novas e anuncia a salvação, do que diz a Sião: 'O teu Deus reina'." Trata-se de salvação e consolação: vv.8-10: "alegria [...] porque Iahweh consolou o seu povo [...] descobriu o braço santo [...] e [...] viram a salvação de nosso Deus." A LXX coloca a frase no futuro "teu Deus reina"

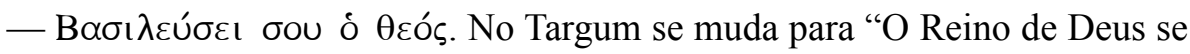
manifestou". Em Is 40,9-10 aparecia uma mensageira, a proclamar: "Eis aqui o vosso Deus!". No Targum está "o Reino de Deus se manifestou". Para Is 24,23, que anunciava que "Iahweh dos Exércitos reina", a frase torna-se "o Reino de Deus manifestar-se-á".

Como observado acima, no Novo Testamento aparece o anúncio do Evangelho aos pobres. Destacavam-se os textos da proclamação do Evangelho na sinagoga de Nazaré (Lc 4,16-30) e o da embaixada de João (Lc 7,19-23 // Mt 11,2-6). Jesus declara: "Hoje se cumpriu aos vossos ouvidos essa passagem da Escritura" (Lc 4,21b); e suas obras tornam-se sinais do tempo da salvação: "Ide contar [...] o que vedes e ouvis" (Lc 7,22b), e apresentam-se feitos como os do oráculo de Isaías.

No ministério de Jesus aparece constantemente o seu amor compassivo e a solicitude benevolente para com todos os que sofrem, os "pobres" de todas as categorias de frágeis e necessitados: aos enfermos, Ele cura (Lc 4,40), aos possessos, liberta ( $\operatorname{Lc} 4,35.41)$; consola a viúva que chora $(\operatorname{Lc} 7,13)$ e ressuscita o filho (Lc 7,14-15); atende ao estrangeiro ( $\operatorname{Lc} 7,2-10)$, acolhe os pequenos (Lc 18,15-17), traz salvação aos pecadores, vai à casa deles (Lc 19,9-10). O discurso de Pedro em Cesareia (At 10,34-43) confirmará a relação entre Is 61,1 e o ministério de Jesus relatando "como Deus o ungiu com o Espírito Santo e com poder, ele que passou fazendo o bem e curando a todos" (At 10,38).

O anúncio do Reino de Deus é uma boa nova para os pobres e demais desafortunados, porque é anúncio de salvação, e por isso consolação. Nesse contexto, não se trata de um ideal de pobreza a cultivar, mas de uma libertação da condição de necessidade ou de sofrimento. Se o pobre também tem uma atitude de humildade e confiança em Deus, esperando de Deus a salvação, 
essa é uma atitude valorizada desde o Antigo Testamento, mas a predileção do Reino como anúncio aos pobres tem seu fundamento e significado principal como anúncio de consolação, libertação e restauração. $O$ fundamento dessa predileção, como bem demonstra Jacques Dupont, ${ }^{33}$ não depende da qualificação moral e religiosa dos pobres e sofredores, mas radica-se no agir de Deus.

É um fundamento teológico. Diz respeito ao modo de reinar de Deus, que cuida dos frágeis. Ao modo de agir de Deus, que atua salvificamente, que tem amor e solicitude, e assim toma em defesa e restauração o pobre, aquele que em condição de dependência, o injustiçado, o sofredor e mesmo o pecador. Deus os toma em proteção com seu amor e atua pela sua libertação da condição de pobre.

Esse modo de agir corresponde ao antigo ideal régio, difundido no Oriente Próximo, e apresenta-se a seu modo na religião de Israel. Conforme mostrado no estudo anterior, o prólogo do Código de Hammurabi (de 1700 a.C.) descreve a missão do rei: "promovi o bem estar do povo"; teria vindo a "fazer surgir a justiça na terra [...] para que o forte não oprima o fraco"; o epílogo repete: "o forte não oprima o fraco", e acrescenta: "o homem oprimido, que está implicado em um processo, venha diante de minha estátua de rei da justiça e leia [...] Que minha estela resolva a questão, ele veja o seu direito, o seu coração se dilate". ${ }^{34}$

J. Dupont relacionou vários textos do Oriente Médio, conforme também visto no estudo retomado, sendo que, para o propósito específico deste artigo, quer-se sublinhar o dado da comunicação intercultural e inter-religiosa desse tema do ideal régio compartilhado. Ele mostrava que já o Código de Ur-Nammu (séc. XXI a.C.) mencionara a proteção ao órfão, à viúva e ao pobre. Outros documentos do Oriente Próximo, abrangendo a Mesopotâmia, Ugarit e o Egito, descreveram a mesma missão do rei de dar pão ao faminto, exercer a justiça para os mais fracos; curar os feridos; vestir os nus, libertar os cativos, cuidar dos que sofrem, defendendo e atendendo ao órfão, à viúva, aos pobres, aos oprimidos, aos necessitados. Um texto que pretendia elogiar Assurbanipal descrevia seu governo como "dias de direito, anos de justiça": remindo cativos, curando enfermos, saciando famintos, vestindo nus. Em outro contexto, temos Shamash, o deus-sol, chamado o "vingador do direito, seguro

\footnotetext{
${ }^{33}$ DUPONT, J., Les Béatitudes, t.2, p. 43-90.

${ }^{34}$ BOUZON, E., O Código de Hammurabi, p. 20.24.109.110.
} 
protetor dos pobres e dos necessitados, das viúvas e dos órfãos, que defende os oprimidos e liberta os cativos". Ramsés IV (séc. XII a.C.) foi festejado em sua entronização com as palavras: "Dia feliz! O céu e a terra estão em festa! pois tu és o grande senhor do Egito. Os que estavam foragidos reentrarão nas cidades". No Conto do Felá pleiteante, o camponês diz ao vizir Reusi: "tu és o pai do órfão, o marido da viúva, o irmão da divorciada, o pajem do que não possui mãe, o que destrói a mentira e estabelece a justiça, o que atende ao clamor do que o chama". Na verdade, todas as pessoas teriam a obrigação de atender aos desfavorecidos, para poder dizer, como no Livro dos Mortos: "Cumpri aquilo que os homens falam e que satisfaz aos deuses; contentei a deus por meio daquele que ele ama: dei pão ao faminto, água ao sedento, vestes ao que está nu, uma passagem ao que não tinha barco". Esperava-se esse auxílio dos deuses. Diz-se a Amon, deus de Tebas — o deus-sol ou Rá: “Amon-Rá, Senhor dos tronos dos dois Países [...] o deus augusto que atende ao chamado do pobre em sua desgraça [...] Senhor do silencioso, que atende ao chamado do pobre. Clamo a ti na minha desgraça e tu vens e me salvas. Àquele que é fraco, dás fôlego, salvas o que está aprisionado [...] salvas o que está na Douat". ${ }^{35}$

Em Israel isso se aplica soberanamente a Deus: à sua justiça salvífica, à sua solicitude para com todos os que sofrem, ou que são frágeis. Estabelece leis em defesa do órfão, da viúva, do estrangeiro, e das pessoas necessitadas. Assim Deus exerce a sua soberania, assim realiza o seu Reino. O tema está nos Salmos. O fiel pode contar com justiça, a misericórdia, a solicitude, a salvação de Deus. De fato, são concepções que aparecem em Dt 10,17; 24,21-22; Jr 21,12; Ez 34,16 e constantemente nos Salmos: S1 9-10; 40,12.18; 68,6-7; $76,8-10 ; 109,31 ; 113,7 \mathrm{ss} ; 140,13 ; 146,7-10$. É na esperança delineada em Ez 34. É a expectativa de Is 61,1ss.7.8.11 e em outros lugares do livro de Isaías, por um Reino de libertação, justiça e paz.

Também no Novo Testamento, no ministério de Jesus, com o anúncio do Reino, descreve-se a manifestação do amor salvífico, do amor compassivo. Sua vida é permeada desse amor e dessa solicitude e seus feitos constituem sinais do Reino. Evangelizar é anunciar o dom do amor salvífico de Deus e o estabelecimento do seu Reino, proporcionar sinais que manifestam esse amor e esse dom. Jesus proclama a Boa Nova do Reino e realiza os seus sinais. São destinatários do anúncio aqueles que aparecem como pobres, necessitados de

${ }^{35}$ DUPONT, J., Béatitudes, t.2, p. 56-62. 
bens, e em todas as categorias de dependência e sofrimento, necessitados de auxílio e misericórdia. São destinatários do amor de Deus e de Sua salvação, revelada e manifestada em Jesus. De certo modo, todas as pessoas estão incluídas no Evangelho.

Ou seja, Jesus anuncia uma boa nova aos pobres e os acolhe demonstrandolhes Seu amor. O ideal nesse aspecto não é tanto o ideal de uma pobreza, e a chamada "pobreza evangélica" terá certamente o seu lugar, mas não como o fundamento da predileção do anúncio e mas de outro modo. O ideal manifestado na proclamação é pelo amor de Deus compassivo, misericordioso e libertador. O fundamento da predileção é teológico, pois é porque é assim solícito o modo de agir de Deus e isso implica na evangelização a ter uma opção fundamental: ter amor compassivo, ser solícito. Ter humildade, confiança e desprendimento, disponibilidade, serão atitudes correspondentes ao Evangelho.

Cabe aprofundar um pouco mais o alcance do espírito das bemaventuranças. A primeira bem-aventurança emprega o termo "pobres"/ $\pi T \omega \chi 0$, sob duas fórmulas diversas: "Bem-aventurados os pobres em espírito ( $\pi T \omega \chi 0 i ̀ ~ T \widetilde{u} \pi v \varepsilon u ́ \mu \alpha T \iota$ ), porque deles é o Reino dos Céus" (Mt 5,3); "Felizes

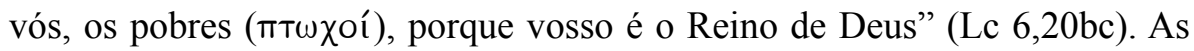
bem-aventuranças seguintes em Lucas aludem às pessoas que têm fome

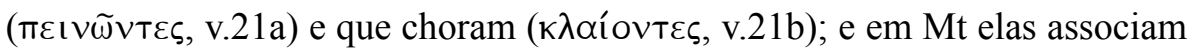
os "pobres em espírito" aos "mansos" (

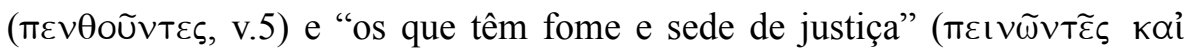

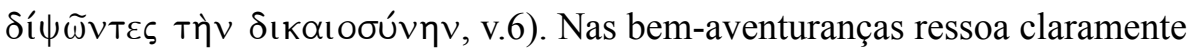
o oráculo de Is 61,1-2 e elas proclamam o Reino de Deus.

Colocadas no início de um discurso formador do comportamento cristão, como o Sermão da Montanha, as bem-aventuranças caracterizam, de modos diversos, a atitude espiritual que o cristão deve ter. Primeiramente elas são felicitações dentro da esperança instaurada pelo Evangelho, sendo igualmente uma práxis para o discípulo. Enquanto no Evangelho lucano as bem-aventuranças observam a condição de pobreza que o discípulo pode sofrer, e anunciam o Reino que liberta, já no evangelho mateano as bem-aventuranças revestem-se de uma atitude espiritual, abrindo a práxis do Sermão da Montanha: aqui, as duas primeiras bem-aventuranças correspondem ao ser manso e humilde. Mais tarde o evangelho mostrará o exemplo de Jesus como manso e humilde (Mt 11,29). As outras bem-aventuranças prolongam essa atitude com os compromissos de promover justiça e paz, de misericórdia, pureza de coração, sem diminuir, mas ainda na expectativa e felicitação do Reino. 
Encontra-se, portanto, no que foi chamado de "espírito das bemaventuranças", o anúncio do Reino e uma proposta espiritual de humildade e mansidão, desprendimento e confiança, compromissos de misericórdia, justiça e paz. Ao mesmo tempo em que anuncia o Evangelho do amor salvífico de Deus, as bem-aventuranças formam os discípulos para a práxis concreta de Jesus.

\section{3. Ênfases do Papa Francisco e feição dialogal da temática}

A fé e a práxis cristã podem ser resumidas no amor salvífico de Deus. O Papa Francisco, em sua Exortação Apostólica Evangelii Gaudium, mostrou, para a hierarquia das verdades da fé cristã, que a mais central é a manifestação do amor Deus em Cristo: ao falar "a partir do coração do Evangelho", afirmou que "Neste núcleo fundamental, o que sobressai é a beleza do amor salvifico de Deus manifestado em Jesus Cristo morto e ressuscitado". ${ }^{36}$ Já para a hierarquia das virtudes, citando S. Tomás de Aquino, afirma que é próprio de Deus agir com misericórdia. O Papa recorda as palavras de Paulo sobre "a fé que atua pelo amor (G1 5,6)", de tal modo que "a misericórdia é a maior de todas as virtudes". ${ }^{37}$ Nisso ressoa 1 Cor 13,13 , que adverte nada ser maior que a caridade.

Como em geral se percebe, o Papa Francisco promove a reforma da Igreja em prosseguimento à renovação e à consciência pastoral e dialogal do Concílio Vaticano II. Assim como se desejou no mesmo Concílio, na constituição Gaudium et Spes, uma Igreja aberta e próxima, em diálogo, solidária com as pessoas, atenta ao mundo e atuante, o Papa Francisco propõe na EG um discernimento do nosso tempo, uma crítica à opressão e à exclusão, um aprofundamento no seguimento de Jesus, um empenho para desencadear novos processos. Para isso, ele propõe aos fiéis amplos círculos de diálogos e a missão de uma Igreja em saída, ao encontro, no serviço, na frutificação e celebração. É como ele descreve e propõe a evangelização.

O Papa constantemente recorda os pobres e assume a opção preferencial pelos pobres. Ele explica essa opção preferencial da Igreja ${ }^{38}$ e entende a sua aplicação no cuidado para com todos os tipos de fragilidade. Desse modo o cuidado para com os frágeis estende-se ao conjunto da criação. ${ }^{39}$ Sobre o

\footnotetext{
${ }^{36}$ EG 36.

${ }^{37} \mathrm{EG} 37$

${ }^{38}$ EG 198.

${ }^{39} \mathrm{EG} 215$.
} 
tema do cuidado da criação ou casa comum, ele desenvolve toda a encíclica Laudato Si'(LS), dirigindo-se a todas as pessoas no mundo de hoje. Ele afirma na LS desejar "entrar em diálogo com todos" ${ }^{40} \mathrm{Na}$ programática exortação Evangelii Gaudium havia contemplado vários âmbitos pastorais, incluindo um lugar especial para a pastoral juvenil. ${ }^{41}$ Mostra que importa escutar os corações e preparar os caminhos. Na exortação Gaudete et Exsultate, sobre o chamado à santidade no mundo atual, o Papa coloca em lugar central a vivência das bem-aventuranças. Destaque-se ainda a proclamação do ano de Jubileu Extraordinário da Misericórdia, para fazer contemplar Jesus como rosto da misericórdia e promover seu maior seguimento. Dali, instituiu um Dia Mundial dos Pobres. Todo o seu pontificado - nos gestos, nas palavras, nos encontros, nos documentos - tem sido permeado desse ensinamento mais central do Evangelho, do amor salvífico e solícito, que se anuncia mediante sinais de solidariedade com os pobres, os frágeis, os que sofrem, e para a inclusão de todos. Essas propostas correspondem às aspirações de uma teologia sistemático-pastoral a partir do Evangelho, bem como aberta aos diálogos em nossos tempos.

Torna-se importante para a teologia sistemático-pastoral considerar o nosso tempo sofrido e desesperançado, escutando os clamores das pessoas, em seus mais variados tipos de exclusões. E toda a criação fragilizada. $\mathrm{Na}$ América Latina se faz uma rememoração dos 40 anos da Conferência de Puebla, em continuidade com os 50 de Medellín, uma oportunidade de assumir de novo as opções preferenciais do Evangelho: pelos pobres e por todos os que sofrem; pela juventude ao mesmo tempo frágil e chamada a ser sujeito de novos processos de libertação. Trata-se de novo, nas igrejas locais e em comunhão com toda a Igreja, de proclamar o espírito das bem-aventuranças. Com a solicitude e o desapego, ter disponibilidade para os serviços do bem, com ajuda dos diálogos e das colaborações.

F. de Aquino Júnior sublinhou que o quinto aniversário do pontificado do Papa Francisco coincidiu com o quinquagésimo de Medellín. Resguardando as especificidades de cada um, bem como as suas relações, pode-se dizer que o caminho aberto em Medellín teve um florescimento em Puebla mediante as opções preferenciais pelos pobres e pelos jovens. As tensões ocorridas durante à preparação e ao longo da recepção do Conferência não impediram

\footnotetext{
${ }^{40}$ LS 3.

${ }^{41}$ EG 105.
} 
que a Igreja entrasse nesta nova etapa evangelizadora. $O$ tema das opções preferenciais tornou-se melhor matizado e mais presente nas conversações teológico-pastorais e no Magistério. Nesse contexto, o Papa Francisco "se mantém evangelicamente firme e criativo nessa tradição e se torna cada vez mais uma das referências espirituais/humanitárias mais importantes de nosso tempo. E para além dos limites do cristianismo e das tradições religiosas". ${ }^{42}$

O tema da presença da teologia latino-americana na teologia do Papa Francisco, em particular na elaboração da encíclica Laudato $S i$ ', é retomado por C. Ferraz. Além de mencionar o método ver-julgar-agir, e a opção preferencial pelos pobres, esse autor sublinha a atenção da encíclica para com as culturas dos povos, salientando como "o papa reconhece a diversidade cultural como dado positivo, valoriza as culturas dos povos e as contribuições que cada uma pode trazer para a solução da crise em questão", de modo que não se deveria silenciar uma cultura. ${ }^{43}$

De tudo isso se vê que convém aprofundar os diálogos. A perspectiva do pluralismo e do diálogo inter-religioso em relação com a Conferência de Medellín foi investigada por W. S. de Barros. Este autor analisou os textos do Concílio Vaticano II na abertura ao diálogo e verificou que havia novo compromisso, com horizontes abertos, porém temas e questões ainda a aprofundar. Verificou que Medellín deu passos especialmente para o diálogo dos cristãos, com um aceno para a colaboração com outras instituições cristãs para "a tarefa de instaurar justiça nas relações humanas"; chegava já a considerar a situação plural e a necessidade de colaboração de outras entidades. Assim, "Medellín traz outra sensibilidade ao povo que sofre e convoca para o comprometimento", o que o faz pensar que isso deveria ser levado "como fundamento e objetivo para o diálogo inter-religioso". ${ }^{44}$

Já R. Panasiewicz tem em conta que o método ver-julgar-agir, adotado em Medellín e em Puebla, embora possa ter recebido críticas, teve valores proféticos e depois foi ampliado. Então propõe como poderia servir ao diálogo inter-religioso, somando-se a outros métodos, bem como a própria temática da libertação conviria ao diálogo, respeitando-se sempre as tradições religiosas e as espiritualidades, e valorizando-se o viés ético.

\footnotetext{
${ }^{42}$ AQUINO JÚNIOR, F. de., 50 anos de Medellíns - 5 anos de Francisco, p. 46.

${ }^{43}$ FERRAZ, C. G., A possível influência da Teologia Latino-Americana na composição da Laudato Si', p. 51-52.

${ }^{44}$ BARROS, W. S., Pluralismo e diálogo inter-religioso na Conferência de Medellín, p. 119-121.
} 
Todos esses estudos colaboram para mostrar a opção preferencial como categoria teológica e aberta ao diálogo,${ }^{45}$ o que se reencontra no Papa Francisco. O Documento de Puebla, como se constatou, articulou o método ver-julgar-agir; e teve uma seção de seu texto dedicada ao diálogo, na qual se buscava, inclusive, escutar as interpelações de não-crentes. Ao mesmo tempo, desdobrava sua reflexão na pauta da evangelização, buscando ações para soluções inspiradas no anúncio do Reino e afinadas com as suas exigências. Constata-se que caberia dentro da missão ir ao encontro das tradições e culturas, e dialogar com seu potencial de contribuição. O tema evangélico do Reino e as atitudes de humildade e desprendimento têm raízes vétero-testamentárias, sendo que elas antes de tudo participaram de uma comunicação maior de caráter inter-religioso e inter-cultural.

O tema fundamental no diálogo aqui em questão é o da misericórdia. Para o Papa Francisco, a proposta principal do evangelho é a misericórdia. Na Bula Misericordiae Vultus, o Papa pontua como a misericórdia é o modo de agir de Deus ${ }^{46}$ e de novo sublinha que em Jesus "os sinais que realiza para com os pecadores, as pessoas pobres, marginalizadas, doentes e atribuladas, decorrem sob o signo da misericórdia", ${ }^{47}$ mostra que a credibilidade da Igreja bem como seu desejo é "oferecer misericórdia". ${ }^{48}$ Ao mesmo tempo, esse não é um tema exclusivo cristão. O papa formula, no início da MV um convite para um diálogo mais amplo. Do mesmo modo que na EG exorta os fiéis para muitos diálogos e na LS busca a todos como interlocutores para amplos diálogos, na MV propõe um diálogo sobre o tema da misericórdia. Como um modesto serviço na valorização desse tema, a autora deste artigo veio a compor um breve artigo intitulado Diálogo da misericórdia, acolhendo contribuições de tradições cristãs, judaicas e de outras tradições religiosas sobre o tema fundamental da misericórdia, como tema inter-religioso e interdisciplinar. ${ }^{49}$

Pode-se considerar que na exortação Gaudete et Exsultate, do Papa Francisco, sobre o chamado à santidade no mundo atual, o coração das ponderações está na proposta central de seguimento das bem-aventuranças. ${ }^{50}$ Ele discorre sobre cada uma das bem-aventuranças. Ao mesmo tempo, faz ver

\footnotetext{
${ }^{45}$ PANASIEWICZ, R., Medellín, p. 693.

${ }^{46}$ MV 9.

${ }^{47}$ MV 8.

${ }^{48}$ MV 10.

${ }^{49}$ FREITAS CARDOSO, M. T. de, Diálogo da misericórdia.

${ }^{50}$ GE 67-94.
} 
o conjunto de todas elas. Percebem-se ali muitos aspectos que se justapõem ou se mesclam: os salvíficos e da libertação do Reino e as atitudes espirituais de operosidade na solicitude pelos outros, de defesa da justiça, de proteção da paz, com as virtudes interiores de humildade, mansidão, desprendimento, desapego, simplicidade e sobriedade, e outros tantos que o Evangelho quer suscitar. Na GE transparece, em linguagem catequética, como essas opções preferenciais do Evangelho se somam e se encontram. Acaba que uma favorece a outra. Todas juntas formam o espírito das bem-aventuranças.

Que se destaquem ainda as duas primeiras mensagens para o Dia Mundial dos Pobres, onde o Papa Francisco exorta a escutar o clamor do pobre. Na primeira dessas mensagens, para o I Dia Mundial dos Pobres, o papa denuncia tantas situações de pobreza:

Conhecemos a grande dificuldade que há, no mundo contemporâneo, de poder identificar claramente a pobreza. E todavia esta interpela-nos todos os dias com os seus inúmeros rostos marcados pelo sofrimento, pela marginalização, pela opressão, pela violência, pelas torturas e a prisão, pela guerra, pela privação da liberdade e da dignidade, pela ignorância e pelo analfabetismo, pela emergência sanitária e pela falta de trabalho, pelo tráfico de pessoas e pela escravidão, pelo exílio e a miséria, pela migração forçada. A pobreza tem o rosto de mulheres, homens e crianças explorados para vis interesses, espezinhados pelas lógicas perversas do poder e do dinheiro. Como é impiedoso e nunca completo o elenco que se é constrangido a elaborar à vista da pobreza, fruto da injustiça social, da miséria moral, da avidez de poucos e da indiferença generalizada! $!^{51}$

$\mathrm{Na}$ leitura do texto completo, vê-se como o Papa mostra vários textos bíblicos e indicações para uma atitude de escuta e de operosidade. Para a mensagem do II Dia Mundial dos Pobres, ele retoma o mesmo tema de que Deus escuta o clamor (e retoma o S1 34,7), mostrando, junto com diversas outras referências bíblicas, que importa concretizar o atendimento do amor salvífico. Ainda nessa segunda mensagem, ele explicita não se tratar de pretender mostrar algum tipo de primazia, mas sim de ser instrumentos do amor de Deus, sendo que o caminho deve passar pelo diálogo e a colaboração:

${ }^{51}$ FRANCISCO, PP., I Dia Mundial dos Pobres. 
Muitas vezes, a colaboração com outras realidades, que se movem impelidas não pela fé, mas pela solidariedade humana, consegue prestar uma ajuda que, sozinhos, não poderíamos realizar. $\mathrm{O}$ fato de reconhecer que, no mundo imenso da pobreza, a nossa própria intervenção é limitada, frágil e insuficiente leva a estender as mãos aos outros, para que a mútua colaboração possa alcançar o objetivo de maneira mais eficaz [...] uma resposta adequada e plenamente evangélica que podemos realizar, é o diálogo entre as diversas experiências e a humildade de prestar a nossa colaboração, sem qualquer espécie de protagonismo [...] Quem se coloca ao serviço é instrumento nas mãos de Deus, para fazer reconhecer a sua presença e a sua salvação". ${ }^{52}$

\section{Conclusão}

Constatam-se algumas das opções fundamentais do Evangelho do Reino: - anúncio do salvífico amor de Deus; - práxis de solicitude e misericórdia, a cuidar de todos e especialmente dos mais frágeis e que mais necessitam, a implantar uma justiça libertadora; - seguimento de Jesus também nas atitudes de humildade e mansidão e desapego. Tais temas constituíram o eixo da reflexão e da proposta pastoral de Puebla. Junto com a opção pelos pobres em suas diversas categorias, fez-se ainda uma opção pela juventude, que pode ser entendida como um desdobramento ou nova aplicação da ideia central. É que Jesus amou a juventude com um tipo de predileção; nela colocou estima e admiração; e uma expectativa de seguimento do Reino mediante o desapego e a solicitude.

O critério e o fundamento das opções preferenciais são teológicos. Dizem respeito ao amor de Deus, núcleo da fé e critério para a práxis. Tratase de uma mensagem do amor divino, dado que "é próprio de Deus agir com misericórdia". A fé no amor de Deus, para ser viva, implica na sua práxis.

Hoje a situação é de grande clamor a Deus, e de apelo aos corações. Como escutar? Como estender as mãos uns aos outros? Observou-se o ideal régio desejado nas culturas do Oriente Médio e compartilhado nos textos bíblicos, que assim participou de uma ampla comunicação de aspirações e de exigências humanitárias. Era a escuta do clamor pelo cuidado dos mais frágeis, em especial do pobre, da viúva, do órfão, do estrangeiro, do pecador, do infeliz.

${ }^{52}$ FRANCISCO, PP., II Dia Mundial dos Pobres. 
As aspirações e exigências humanitárias podem encontrar-se presentes e tornar-se mais atuantes na colaboração entre as várias possibilidades de diálogo ecumênico, inter-religioso e intercultural. Os diálogos são buscados em novos contextos e entre diferentes culturas, assim como nas abordagens complementares de diversas disciplinas, as contribuições de cada uma e de todas, no respeito ao lugar de cada qual, com os matizes de suas expressões diversas. As opções preferenciais permanecem temas a aprofundar, para a pastoral e para uma teologia em diálogo.

\section{Referências bibliográficas}

AQUINO JÚNIOR, F. 50 anos de Medellín - 5 anos de Francisco: Perspectivas teológico-pastorais. Perspectiva Teológica, v.50, n.1, p. 41-58, jan./abr. 2018. BAGGIO, S.; LORSCHEIDER, A.; CORRIPIO AHUMADA, E. Apresentação. In: CELAM. Puebla: A Evangelização no presente e no futuro da América Latina. Petrópolis: Vozes, 1979. p. 49-52.

BARROS, W. S. Pluralismo e diálogo inter-religioso na Conferência de Medellín. Rever, v.18, n.2, p. 113-123, mai/ago 2018.

BÍBLIA de Jerusalém. Nova edição revista e ampliada. São Paulo: Paulus, 2002.

BOUZON, E., O Código de Hammurabi: introdução, tradução e comentários de E. Bouzon. Petrópolis: Vozes, 1976.

CALDAS AULETE. Pobre. In: Dicionário Contemporáneo da Língua Portuguesa. 2 ed. brasileira (revista, atualizada e aumentada). Rio de Janeiro: Ed. Delta S.A., 1970. p. 2857. v.4.

CELAM. Puebla: A Evangelização no presente e no futuro da América Latina. Petrópolis: Vozes, 1979.

DUPONT, J. Les Béatitudes. Paris, J. Gabalda et Cie., 1965. t.2 (La Bonne Nouvelle).

DUPONT, J. Les Béatitudes. Paris, J. Gabalda et Cie., 1965. t.3 (Les Évangélistes).

FERRAZ, C. G. A possível influência da Teologia Latino-Americana na composição da Laudato Si'. Pesquisas em Teologia, v.1, n.1, p. 38-54, jan./ jun. 2018. 
FRANCISCO, PP. I Dia Mundial dos Pobres: Não amemos com palavras, mas com obras. Disponível em: <http://w2.vatican.va/content/francesco/ $\mathrm{pt} / \mathrm{messages} /$ poveri/documents/papa-francesco_20170613_messaggio-igiornatamondiale-poveri-2017.html >. Acesso em: 5 fev. 2019.

FRANCISCO, PP. II Dia Mundial dos Pobres: Este pobre clama e o Senhor o escuta. Disponível em: <http://w2.vatican.va/content/francesco/ pt/messages/poveri/documents/papa-francesco_20170613_messaggio-igiornatamondiale-poveri-2017.html>. Acesso em: 5 fev. 2019.

FRANCISCO, PP. Carta encíclica Laudato Si', sobre o cuidado da casa comum. São Paulo: Paulus / Loyola, 2015.

FRANCISCO, PP. Exortação apostólica Evangelii Gaudium, sobre o anúncio do Evangelho no mundo atual. São Paulo: Loyola, 2013.

FRANCISCO, PP. Exortação apostólica Gaudete et exsultate, sobre o chamado à santidade no mundo atual. São Paulo: Paulinas, 2018.

FRANCISCO, PP. Misericordiae Vultus. Bula de proclamação do Jubileu Extraordinário da Misericórdia. São Paulo: Paulinas, 2015.

FREITAS CARDOSO, M. T. A predileção evangélica do pobre. In: ALMEIDA, E. de., Coletânea. Rio de Janeiro: Lumen Christi, 1991. p. 131-174. t.2.

FREITAS CARDOSO, M. T. Diálogo da misericórdia: Estudo sobre um tema da Bula Misericordiae Vultus. Atualidade Teológica, v.20, n. 54, p. 599-622, set./dez. 2016.

GÉLIN, A. Os Pobres que Deus ama. São Paulo: Paulinas, 1973.

GEORGES, A. A Pobreza segundo o Antigo Testamento. In: DUPONT, J. et alii, A Pobreza Evangélica. São Paulo: Paulinas, 1976. p. 12-13.

JOÃO PAUlO II, PP. Discurso inaugural. In: CELAM. Puebla: A Evangelização no presente e no futuro da América Latina. Petrópolis: Vozes, 1979. p. 15-24.

LOSS, N. M. Il Tema della Povertà nei Libri Storici e Profetici dell'Antico Testamento. In: ASSOCIAZIONE BIBLICA ITALIANA (ABI), Evangelizare Pauperibus. Atti della XXIV Settimana Biblica. Brescia: Paidea, 1978. p. 55-56.

MARTIN-ACHARD, R. ' $n h$ II. Essere Misero. In: C. WESTERMANN, 
C.; JENNI, -E. Dizionario Teologico dell'Antico Testamento. Casalle Monserato: Editrice Marietti, 1982. t.2. col. 307.

NUEVO TESTAMENTO trilingue. Madrid: Biblioteca de Autores Cristianos, 1977.

PANASIEWICZ, R. Medellín: fonte de inspiração para uma metodologia do diálogo inter-religioso. Horizonte, v.16, n.50, p. 677-697, mai./ago., 2018.

SEPTUAGINTA. Stuttgart: Deutsche Bibelgesellschaft, 1979.

\author{
Maria Teresa de Freitas Cardoso \\ Doutora em Teologia pela Pontifícia \\ Universidade Católica do Rio de Janeiro \\ Docente do Departamento de Teologia da Pontifícia \\ Universidade Católica do Rio de Janeiro \\ Rio de Janeiro / RJ - Brasil \\ E-mail:mtfcardoso@puc-rio.br
}

Recebido: 30/04/19

Aprovado: 07/08/19 